\section{PERLINDUNGAN HUKUM TERHADAP PASIEN DALAM PELAYANAN KESEHATAN BERDASARKAN UNDANG-UNDANG NOMOR 36 TAHUN $2009^{1}$ \\ Oleh: Deo Rambet ${ }^{2}$}

\begin{abstract}
ABSTRAK
Tujuan dilakukannya penelitian ini yakni untuk mengetahui bagaimana wewenang dokter dalam pelayanan kesehatan terhadap pasien dan bagaimana perlindungan hukum terhadap hak pasien dalam pelayanan kesehatan berdasarkan Undang-undang Nomor 36 Tahun 2009 yang dengan metode penelitian hukum normatif disimpulkan: 1 . Wewenang dokter dalam pelayanan kesehatan adalah mewawancarai pasien, memeriksa fisik dan mental pasien, menentukan pemeriksaan penunjang, melakukan diagnose, menentukan pengobatan pasien, menulis resep dan alat kesehatan, meracik dan menyerahkan obat kepada pasien yang harus didasarkan pada kaidah moral yakni menghormati martabat manusia, berbuat baik, tidak berbuat yang merugikan pasien dan keadilan. 2 . Perlindungan hukum terhadap hak pasien dalam pelayanan kesehatan berdasarkan Undang-undang Nomor 36 Tahun 2009 diberikan dalam bentuk hak gugat perdata untuk menuntut ganti rugi dalam hal pelayanan kesehatan telah menimbulkan kerugian pasien akibat kesalahan atau kelalaian dalam pelayanan kesehatan yang diterimanya berupa terganggunya kesehatan atau cacat karena pelayanan kesehatan yang tidak sesuai standard.
\end{abstract}

Kata kunci: pasien; pelayanan kesehatan;

\section{PENDAHULUAN}

\section{A. Latar Belakang Masalah}

Saat ini masyarakat semakin berkembang, dapat mengakses informasi dari berbagai sumber seperti internet melalui dunia maya, masyarakat semakin cerdas dan semakin tahu akan hak-haknya. Apalagi kesehatan adalah hak asasi manusia dan masyarakat berhak untuk mendapatkan derajat kesehatan yang setinggi-tingginya, sehingga apabila hak

\footnotetext{
1 Artikel Skripsi. Dosen Pembimbing: Veibe V. Sumilat, $\mathrm{SH}, \mathrm{MH}$; Dr. Anna S. Wahongan, $\mathrm{SH}, \mathrm{MH}$

2 Mahasiswa pada Fakultas Hukum Unsrat, NIM 14071101334
}

mereka tidak diberikan maka masyarakat khususnya pasien bukan hanya menerima seperti dulu atau menganggap dokter sebagai dewa. Dewasa ini pasien tidak pasif malah menjadi aktif dan tidak segan untuk memperjuangkan hak untuk mendapatkan perlindungan hukum dan bagi tenaga-tenaga kesehatan hal ini untuk menjadi momok atau rasa takut, karena tenaga kesehatan, dokter, perawat dan bidan bukanlah malaikat, tetapi manusia biasa dengan segala kelebihan dan kelemahannya. Dokter dan tenaga kesehatan lainnya adalah tenaga kesehatan yang sangat dipercaya, yang pada prinsipnya mempunyai perilaku yang mendatangkan kebajikan, benar dan bertanggung jawab. Selain itu dokter dalam pelayanan kesehatan harus melakukan wewenangnya sesuai dengan ketentuan yang berlaku, agar hak-hak pasien terlindungi, yang merupakan hal yang menarik untuk dibahas.

\section{B. Perumusan Masalah}

1. Bagaimana wewenang dokter dalam pelayanan kesehatan terhadap pasien?

2. Bagaimana perlindungan hukum terhadap hak pasien dalam pelayanan kesehatan berdasarkan Undang-undang Nomor 36 Tahun 2009?

\section{Metode Penelitian}

Penelitian ini merupakan penelitian hukum normatif.

\section{PEMBAHASAN}

\section{A. Wewenang Dokter dalam Pelayanan Kesehatan}

Pelayanan kesehatan diselenggarakan berdasarkan pada kesepakatan antara dokter dengan pasien dalam upaya untuk pemeliharaan kesehatan, pencegahan penyakit (preventif), peningkatan kesehatan (promotif), pengobatan penyakit (kuratif) dan pemulihan kesehatan (rehabilitatif), yang kesemuanya harus didasarkan pada nilai ilmiah, manfaat, keadilan, kemanusiaan, keseimbangan, serta perlindungan dan keselamatan pasien. Yang dimaksudkan dengan $:^{1}$

a. Nilai ilmiah adalah praktik kedokteran berdasarkan pada ilmu pengetahuan

\footnotetext{
1 Adriyati, dkk., Penyelenggaraan Praktik Kedokteran yang Baik di Indonesia, Konsil Kedokteran Indonesia, Jakarta, 2006, hlm. 6.
} 
dan teknologi yang diperoleh, baik dalam pendidikan maupun pengalaman, serta etika profesi.

b. Asas manfaat adalah penyelenggaraan praktik kedokteran harus memberikan manfaat bagi kemanusiaan dalam rangka mempertahankan dan meningkatkan derajat kesehatan masyarakat.

c. Asas keadilan adalah penyelenggaraan praktik kedokteran yang memberikan pelayanan secara adil dan merata kepada setiap orang dengan biaya yang terjangkau dengan tetap memberikan pelayanan yang bermutu.

d. Asas kemanusiaan adalah penyelenggaraan praktik kedokteran yang memberikan perlakuan yang sama dengan tidak membedakan suku, bangsa, agama, ras, gender, status sosial, ekonomi, dan pandangan politik.

e. Asas keseimbangan adalah penyelenggaraan praktik kedokteran yang tetap menjaga keserasian serta keselarasan antara kepentingan individu dan masyarakat.

f. Asas perlindungan dan keselamatan adalah penyelenggaraan praktik kedokteran tidak hanya memberikan pelayanan kesehatan semata, tetapi harus mampu memberikan peningkatan derajat kesehatan dengan tetap memerhatikan perlindungan dan keselamatan pasien. Walaupun seorang dokter tidak dapat menjamin kesembuhan pasien, namun setiap dokter senantiasa berupaya untuk meringankan penderitaan pasien. .

Wewenang dokter dalam pelayanan kesehatan sesuai dengan pendidikan dan kompetensi yang dimiliki, terdiri atas : ${ }^{2}$

1. Mewawancarai pasien.

2. Memeriksa fisik dan mental pasien.

3. Menentukan pemeriksaan penunjang.

4. Melakukan diagnosis.

5. Menentukan penatalaksanaan dan pengobatan pasien.

6. Melakukan tindakan kedokteran atau kedokteran gigi.

2 Pasal 20 Peraturan Menteri Kesehatan Nomor 2052/Menkes/Per/X/2011 tentang Izin Praktek dan Pelaksanaan Praktik Kedokteran.
7. Menulis resep obat dan alat kesehatan.

8. Menerbitkan surat keterangan dokter atau dokter gigi.

9. Menyimpan obat dalam jumlah dan jenis yang diizinkan.

10. Meracik dan menyerahkan obat kepada pasien, bagi yang praktik di daerah terpencil yang tidak ada apotek.

Kewenangan dokter di atas harus dilaksanakan berdasarkan kesepakatan yang dilakukan secara maksimal sesuai dengan kewenangan dan kompetensinya. Kewenangan dan kompetensinya harus berdasarkan pada 4 (empat) kaidah dasar moral, yaitu : ${ }^{3}$

a. Menghormati martabat manusia (respect for person)

Yang dimaksudkan dengan menghormati martabat manusia: Pertama, setiap individu (pasien) harus diperlakukan sebagai manusia yang memiliki otonomi (hak untuk menentukan nasib diri sendiri) dan kedua, setiap manusia yang otonominya berkurang atau hilang perlu mendapatkan perlindungan.

b. Berbuat baik (beneficence)

Selain menghormati martabat manusia, dokter juga harus mengusahakan agar pasien yang dirawatnya terjaga keadaan kesehatannya (patient welfare). Pengertian berbuat baik diartikan bersikap ramah atau menolong, lebih dari sekadar memenuhi kewajiban.

c. Tidak berbuat yang merugikan (non-maleficence)

Praktik kedokteran haruslah memilih pengobatan yang paling kecil risikonya dan paling besar manfaatnya. Pernyataan kuno: first, do no harm tetap berlaku dan harus diikuti.

d. Keadilan (justice)

Perbedaan kedudukan sosial, tingkat ekonomi, pandangan politik, agama dan paham kepercayaan, kebangsaan dan kewarganegaraan, status perkawinan, serta perbedaan gender tidak boleh dilakukan dan tidak dapat mengubah sikap dokter terhadap pasiennya. Tidak ada pertimbangan lain selain kesehatan pasien yang menjadi perhatian utama dokter. Prinsip dasar ini juga mengakui

${ }^{3}$ Adriyati, dkk., Op-cit, hlm. 7. 
adanya kepentingan masyarakat sekitar pasien yang harus dipertimbangkan.

Pelaksanaan asas dan kaidah praktik kedokteran Indonesia di atas bertujuan untuk $: 4$

1. Memberikan perlindungan kepada pasien.

2. Mempertahankan dan meningkatkan mutu pelayanan medik.

3. Memberikan kepastian hukum kepada masyarakat, dokter, dan dokter gigi.

Dalam keadaan darurat guna penyelamatan nyawa, dokter dapat melakukan tindakan kedokteran atau kedokteran gigi di luar kewenangan klinisnya sesuai dengan kebutuhan medis. Namun demikian harus tetap dilakukan sesuai dengan standar profesi.

Yang dimaksud dengan standar profesi adalah batasan kemampuan (knowledge, skill and professional attitude) minimal yang harus dikuasai oleh seorang dokter atau dokter gigi untuk dapat melakukan kegiatan profesionalnya pada masyarakat secara mandiri yang dibuat oleh organisasi profesi. (Pasal 1 angka 10 Peraturan Menteri Kesehatan Nomor 2052/MENKES/PER/X/2011 tentang Izin Praktik dan Pelaksanaan Praktik Kedokteran).

Sehubungan dengan kewenangan melakukan praktik kedokteran dalam pelayanan kesehatan, maka seorang dokter wajib melakukan hal-hal sebagai berikut $:^{5}$

a. Mengutamakan kepentingan pasien.

b. Memperlakukan pasien secara sopan dan penuh perhatian.

c. Menghormati martabat dan privasi pasien.

d. Mendengarkan pasien dan menghormati pandangan serta pendapatnya.

e. Memberikan informasi kepada pasien secara jelas.

f. Memberikan edukasi untuk meningkatkan kesehatan.

g. Menghormati hak pasien dalam pengambilan keputusan tentang pelayanan yang akan diberikan.

h. Mempertahankan dan memperbaharui pengetahuan serta keterampilan profesi.

\footnotetext{
${ }^{4}$ H. Zaeni Asyhadie, Aspek-aspek Hukum Kesehatan di Indonesia, PT Raja Grafindo Persada, Jakarta, 2018, hlm. 41.

${ }^{5}$ Loc-cit.
}

i. Menyadari keterbatasan kompetensi profesi.

j. Dapat dipercaya dan jujur.

k. Menghormati dan menyimpan informasi rahasia pasien.

I. Menghormati agama dan kepercayaan pasien.

$\mathrm{m}$. Senantiasa berusaha mengurangi risiko yang akan menimpa pasien.

$\mathrm{n}$. Menghindari penyalahgunaan wewenang sebagai dokter.

o. Bekerja sama antarsejawat untuk memberi pelayanan kedokteran terbaik.

p. Melaksanakan praktik kedokteran sesuai dengan ketentuan yang berlaku.

q. Melakukan pertolongan darurat atas dasar perikemanusiaan, kecuali jika ada orang lain yang bertugas dan mampu melakukannya.

Dalam rangka menyelenggarakan praktik kedokteran yang baik, pelayanan kesehatan dilaksanakan berdasarkan buku Penyelenggaraan Praktik Kedokteran Yang Baik di Indonesia yang disusun oleh sebuah tim yang dibentuk oleh Konsil Kedokteran Indonesia, menyatakan bahwa seorang dokter harus bertindak : ${ }^{6}$

1. Menyediakan asuhan klinis yang baik.

2. Memilih asuhan yang baik.

3. Mempertahankan praktik kedokteran yang baik.

4. Kerja sama dengan sejawat.

Sesuai dengan yang diuraikan dalam buku Penyelenggaraan Praktik Kedokteran, tindakan dokter di atas akan diuraikan secara ringkas sebagai berikut:

1. Menyediakan Asuhan Klinis yang Baik

Yang dimaksudkan dengan asuhan klinis yang baik adalah dokter dalam memberikan pelayanan klinis kepada pasien haruslah melakukan tindakan yang baik, yaitu : ${ }^{7}$

1) Menilai keadaan pasien yang adekuat berdasarkan anamnesis dan pemeriksaan fisik, apabila diperlukan juga melakukan pemeriksaan tambahan yang sesuai.

2) Melakukan atau merencanakan pemeriksaan lanjutan, dan melakukan terapi apabila diperlukan.

\footnotetext{
${ }^{6}$ Bahder Johan Nasution, Hukum Kesehatan Pertanggung jawaban Dokter, Rineka Cipta, Jakarta, 2015, hIm. 86.

$7 \mathrm{lbid}, \mathrm{hlm} .87$.
} 
3) Melakukan tindakan yang tepat.

4) Melakukan tindakan segera apabila diperlukan.

5) Merujuk pasien kepada dokter lain yang sesuai, bila ada indikasi.

Dalam melakukan tindakan atau pelayanan di atas dokter haruslah bersikap : ${ }^{8}$

a) Mengenali dan bekerja di dalam batas-batas kompetensi profesi.

b) Senantiasa bersedia berkonsultasi dengan sejawat.

c) Meyakini dirinya senantiasa dalam keadaan yang kompeten (mampu dan sehat baik fisik maupun mental) ketika menegakkan diagnosis, merencanakan, dan memberikan terapi.

d) Menjaga agar rekam medis selalu jelas, akurat, dapat dibaca dan sesuai dengan keadaan pasien waktu ditulis, serta berisi temuan klinis yang relevan, keputusan yang diambil sewaktu, penjelasan yang diberikan kepada pasien, dan jenis obat atau tindakan yang direncanakan atau dilakukan.

e) Senantiasa saling memberi informasi kepada sejawat tentang pasien rawat bersama.

f) Memberikan terapi untuk mengurangi penderitaan atau rasa sakit kepada pasien yang tidak mempunyai harapan sembuh.

g) Resep harus ditulis dengan tata cara yang benar, jelas dan terbaca.

h) Tidak boleh merekomendasikan kepada pasien tentang pemeriksaan, terapi, atau melakukan rujukan, yang tidak bermanfaat bagi pasien.

i) Menjelaskan kepada pasien mengenai manfaat dan efek yang tidak diinginkan dari obat/bahan dan atau tindakan, sebelum dan sesudah terapi dan menuliskannya di dalam rekam medis.

j) Melaporkan hasil terapi, tindakan, dan/atau efek obat yang tidak diinginkan kepada Komite Medik Rumah Sakit atau sesuai dengan ketentuan yang berlaku untuk kepentingan peningkatan mutu asuhan klinis.

k) Memanfaatkan segala sumber daya yang ada secara efisien.
Apabila terdapat keterbatasan sarana dan prasarana, dokter harus menentukan keputusan terapi atau tindakan secara bijak. Keputusan ini secara proporsional disampaikan kepada pasien dan ditulis dalam rekam medis. Jika dokter mempunyai alasan yang baik untuk berpendapat bahwa kemampuannya untuk memberikan terapi secara tepat kepada pasien terhambat secara serius karena kekurangan tempat bertindak, kekurangan peralatan yang diperlukan atau kekurangan sarana lainnya, maka hal ini harus disampaikan kepada yang berwenang untuk dapat memperbaikinya. Dokter harus mencatat kekhawatirannya ini serta langkah-langkah yang sudah dilakukan dalam catatan khusus.

\section{Memilih Asuhan yang Baik}

Memilih asuhan yang baik maksudnya dokter dalam melakukan pelayanan kesehatan haruslah didasarkan pada penilaian keadaan klinis pasien dan efektivitas pemeriksaan. Demikian juga dengan keputusan penentuan terapi. Dalam melakukan hal tersebut tidak boleh dipengaruhi oleh gaya hidup pasien, budaya, kepercayaan, ras, warna kulit, jenis kelamin, cacat, umur, dan keadaan sosial ekonomi. Dokter tidak boleh menolak atau menunda terapi yang diperlukan.

Jika dokter merasa bahwa pasien tidak yakin akan saran atau terapi atau tindakan yang akan diberikan, maka dokter harus menjelaskan sekali lagi dengan lebih rinci atas saran, terapi dan tindakan yang akan dilakukan kepada pasien. Selanjutnya, dokter mengatakan kepada pasien tentang haknya untuk pergi atau berobat ke dokter lain untuk memperoleh opini kedua.

Di samping itu dokter tidak boleh menolak untuk mengobati pasien penyakit menular yang berisiko terhadap dirinya. Jika penyakit pasien berisiko terhadap dirinya, maka dokter harus melindungi dirinya sebelum melakukan pemeriksaan atau memberikan pelayanan medis.

\section{Mempertahankan Praktik Kedokteran} yang Baik

Banyak hal yang bisa dilakukan oleh dokter dalam rangka mempertahankan praktik kedokteran yang baik. Dalam buku Penyelenggaraan Praktik Kedokteran yang Baik di Indonesia antara lain dikemukakan : 
1. Dokter harus meningkatkan pengetahuan dan keterampilan terkini selama berprofesi.

2. Setiap dokter yang menjalankan praktik wajib mengikuti pendidikan dan pelatihan kedokteran yang diselenggarakan oleh institusi pendidikan atau lembaga lain yang terakreditasi oleh organisasi profesi dalam rangka penyerapan perkembangan ilmu pengetahuan dan teknologi kedokteran.

Selain itu dokter juga harus mempertahankan kualitas pelayanan dan juga harus mempunyai kepedulian yang tinggi terhadap keselamatan pasien dan harus bekerja sama dengan sejawat dan/atau tenaga kesehatan lain. Unruk itu dokter harus : ${ }^{9}$

1. Membuat rekam medik secara benar dan baik.

2. Mengikuti secara rutin dan sistematis audit klinis atau medis. Dokter harus merespons atau menindaklanjuti hasil audit tersebut untuk meningkatkan kualitas penyelenggaraan praktik, antara lain dengan mengikuti pendidikan dan pelatihan lanjutan.

3. Membuat laporan, catatan pribadi, dan melaporkan tentang kejadian yang tidak menyenangkan pada forum audit internal untuk membantu menurunkan risiko terhadap pasien.

4. Dokter yang bekerja di rumah sakit dan sarana pelayanan kesehatan lainnya harus bersedia memberikan kontribusi dalam upaya peningkatan kualitas praktik kedokteran di tempat dia bekerja dalam bentuk pelatihan informal ataupun formal.

5. Dokter yang bekerja di rumah sakit pendidikan dan jejaringnya harus memberikan kontribusi pelatihan dan pengajaran pada pendidikan mahasiswa (calon dokter) atau program pendidikan dokter lainnya sesuai dengan tujuan pendidikan dan kompetensi yang akan dicapai.

6. Dokter yang mempunyai tanggung jawab untuk mengajar diharuskan untuk mengembangkan pengetahuan, keterampilan, dan sikap profesionalitas, sebagai seorang tenaga pengajar yang kompeten. Dokter juga harus melaksanakan proses pembelajaran dengan benar dan baik.

7. Dalam pelayanan kesehatan, dokter harus senantiasa memberikan penilaian terhadap jalannya asuhan medis di sarana tempatnya bekerja dan memberikan rekomendasi sesuai kompetensi dan standar yang diketahui kepada manajemen sarana pelayanan kesehatan.

8. Dalam proses pengajaran, dokter sebagai penilai harus jujur dan objektif dalam memberikan penilaian kinerja dokter lain termasuk pada dokter yang dilatih atau dibimbingnya. Penilaian yang tidak jujur akan berisiko terhadap pasien.

9. Seluruh informasi yang relevan dan berhubungan dengan kompetensi dan kinerja dokter harus dinilai secara objektif. Dokter sebagai penilai harus memberikan komentar yang jujur ketika membuat rekomendasi atau laporan kinerja sejawat atau dokter yang dibimbingnya.

Masih dalam rangka mempertahankan praktik kedokteran yang baik, dalam tahap awal melaksanakan hubungan antara dokter dan pasien, dokter harus melakukan komunikasi yang baik berdasarkan saling percaya dan saling menghormati. Komunikasi yang baik meliputi : ${ }^{10}$

1. Mendengarkan keluhan, menggali informasi, dan menghormati pandangan serta kepercayaan pasien yang berkaitan dengan keluhannya.

2. Memberikan informasi yang diminta atau yang diperlukan tentang kondisi, diagnosis, terapi dan prognosis pasien, serta rencana perawatannya. Ini harus dilaksanakan dengan menggunakan cara yang bijak dan bahasa yang dimengerti pasien. Termasuk informasi tentang tujuan pengobatan, pilihan obat yang diberikan, cara pemberian serta pengaturan dosis obat, dan kemungkinan efek samping obat yang mungkin terjadi.

\footnotetext{
${ }^{9}$ H. Zaeni Asyhadie, Op-cit, hlm. 46-47.
}

\footnotetext{
${ }^{10}$ Adriyati, dkk., Op-cit, hlm. 26.
} 
3. Memberikan informasi tentang pasien serta tindakan kedokteran yang dilakukan kepada keluarganya, setelah mendapat persetujuan pasien.

Jika seorang pasien mengalami kejadian yang tidak diharapkan selama dalam perawatan dokter, dokter yang bersangkutan atau penanggung jawab pelayanan kedokteran harus menjelaskan keadaan yang terjadi akibat jangka pendek atau jangka panjang dan rencana tindakan kedokteran yang akan dilakukan secara jujur dan lengkap serta menunjukkan empati. Jika pasien adalah seorang dewasa yang tidak mampu menerima penjelasan dokter, maka penjelasan harus diberikan kepada mereka yang bertanggung jawab terhadap pasien, keluarga dekat atau teman lainnya yang ikut terlibat dalam perawatan pasien tersebut. Jika pasien adalah seorang anak, keadaan ini harus disampaikan kepada orang yang bertanggung jawab secara pribadi atau kepada pasien jika dinilai sudah cukup matang untuk mengerti kejadian tersebut.

4. Kerja Sama dengan Sejawat

Sebelumnya telah dikemukakan, bahwa jika dalam pelaksanaan praktik kedokteran terdapat keterbatasan sarana dan prasarana dokter menentukan keputusan terapi atau tindakan secara bijak. Salah satu keputusan terapi atau tindakan bijak tersebut adalah merujuk pasien ke teman sejawat atau dokter spesialis yang sesuai dengan hasil diagnosisnya. Rujukan bertujuan untuk mendapatkan advis, pemeriksaan atau tindakan lanjutan bagi pasien.

Dokter yang menerima rujukan, sesuai dengan etika profesi, wajib menjawab/memberikan advis tindakan atau terapi dan mengembalikannya kepada dokter yang merujuk. Dalam keadaan tertentu dokter penerima rujukan dapat melakukan tindakan atau perawatan lanjutan dengan persetujuan dokter yang merujuk dan pasien.

Pada pasien rawat inap, sejak awal pengambilan kesimpulan sementara (hasil diagnosis), dokter dapat menyampaikan kepada pasien kemungkinan untuk dirujuk kepada sejawat lain karena alasan kompetensi. Rujukan dimaksud dapat bersifat advis, rawat bersama atau alih rawat. Pada saat meminta persetujuan pasien untuk dirujuk, dokter harus memberi penjelasan tentang alasan, tujuan, dan konsekuensi rujukan termasuk biaya. Dalam hal ini pasien berhak memilih dokter rujukan, dan dalam rawat bersama harus ditetapkan dokter penanggung jawab utama.

Hal yang lain berkaitan bekerja sama dengan sejawat, dokter harus memperlakukan teman sejawat tanpa membedakan jenis kelamin, ras, kecacatan, agama kepercayaan, usia, status sosial atau perbedaan kompetensi yang dapat merugikan hubungan profesional antar sejawat. Dan seorang dokter tidak dibenarkan mengkritik teman sejawat melalui pasien yang mengakibatkan turunnya kredibilitas sejawat tersebut.

Kadang kala kasus (penyakit) tertentu dalam penyelenggaraan praktik kedokteran dilakukan melalui kerja sama dalam tim multidisiplin. Apabila bekerja dalam sebuah tim, dokter harus : ${ }^{11}$

1. Menunjuk ketua tim selaku penanggung jawab.

2. Tidak boleh mengubah akuntabilitas pribadi dalam perilaku keprofesian dan asuhan yang diberikan.

3. Menghargai kompetensi dan kontribusi anggota tim.

4. Memelihara hubungan profesional dengan pasien.

5. Berkomunikasi secara efektif dengan anggota tim di dalam dan di luar tim.

6. Memastikan agar pasien dan anggota tim mengetahui dan memahami siapa yang bertanggung jawab untuk setiap aspek pelayanan pasien.

7. Berpartisipasi dalam review secara teratur, audit dari standar dan kinerja tim, serta menentukan langkah-langkah yang diperlukan untuk memperbaiki kinerja dan kekurangan tim.

8. Menghadapi masalah kinerja dalam pelaksanaan kerja tim dilakukan secara terbuka dan sportif.

Dalam pelayanan kesehatan, jika seorang dokter berhalangan dalam melaksanakan/penyelenggaraan praktik kedokteran, dokter tersebut harus menentukan dokter pengganti serta mengatur proses pengalihan yang efektif dan komunikatif dengan dokter pengganti. Dokter pengganti harus diinformasikan kepada pasien.

$11 \mathrm{lbid}, \mathrm{hlm} .28$. 
Dokter yang berhalangan harus memastikan bahwa dokter pengganti mempunyai kemampuan, pngalaman, pengetahuan, dan keahlian untuk mengerjakan tugasnya sebagai dokter pengganti. Dokter pengganti harus tetap bertanggung jawab kepada dokter yang digantikan atau ketua tim dalam asuhan medis.

Dokter yang berhalangan tidak diperkenankan untuk mendelegasikan wewenang kepada perawat, mahasiswa kedokteran, peserta program pendidikan dokter spesialis, atau dokter pengganti dalam hal pengobatan atau perawatan atas nama dokter yang merawat. Pendelegasian wewenang ini harus disesuaikan dengan kompetensi dalam melaksanakan prosedur dan pemberian terapi sesuai dengan peraturan yang berlaku. Dokter yang mendelegasikan tetap menjadi penanggung jawab atas penanganan pasien secara keseluruhan.

\section{B. Perlindungan Hukum terhadap Hak Pasien dalam Pelayanan Kesehatan}

Pada prinsipnya tujuan dikeluarkan Undang-Undang Nomor 36 Tahun 2009 tentang Kesehatan adalah untuk memberikan perlindungan kepada pasien, sama dengan makna yang dituangkan dalam Undang-Undang Nomor 29 Tahun 2004 tentang Praktik Kedokteran yang mengatakan, pengaturan praktik kedokteran bertujuan untuk :

1. Memberikan perlindungan kepada pasien.

2. Mempertahankan dan meningkatkan mutu pelayanan medis yang diberikan oleh dokter dan dokter gigi.

3. Memberikan kepastian hukum kepada masyarakat, dokter, dan dokter gigi.

Hak dan kewajiban dalam kehidupan bermasyarakat, berbangsa, dan bernegara, merupakan dua hal yang korelatif. Artinya, dalam suatu atau sebuah hubungan hukum, maka hak dari salah satu pihak merupakan keharusan bagi pihak yang lain. Dalam memberikan pelayanan kesehatan, dokter atau tenaga kesehatan yang berhubungan langsung dengan pasien sudah seharusnya melakukan yang terbaik untuk pasien atau masyarakat. Itu merupakan kewajiban yang umum yang harus dipenuhi oleh dokter atau tenaga kesehatan.
Sebaliknya, pasien dan masyarakat, selain berhak menerima pelayanan kesehatan yang baik juga berkewajiban mematuhi semua anjuran dokter maupun tenaga medis lainnya atau tenaga kesehatan untuk mencegah hasil pengobatan yang negatif maupun yang tidak diinginkan. ${ }^{12}$

Setiap orang berhak menerima atau memperoleh sebagian atau seluruh tindakan pertolongan yang akan diberikan kepadanya. Setelah menerima dan memahami informasi mengenai undakan tersebut secara lengkap. Hak menerima atau menolak tidak berlaku pada penderita penyakit yang penyakitnya dapat secara cepat menular ke dalam masyarakat yang lebih luas, keadaan seseorang yang tidak sadarkan diri atau, orang dalam keadaan gangguan mental berat. Dalam kenyataan sehari-hari hak pasien di sini adalah hak akan informasi yang jelas terhadap tindakan yang akan diterimanya. Adakalanya pasien tidak memahami hal tersebut dan percaya saja kepada dokternya.

Diminta atau tidak, seyogyanya seorang tenaga kesehatan atau dokter memberikan informasi kepada pasien dengan penjelasan yang betul-betul dipahami pasien sesuai dengan tingkat pendidikannya. Hak pasien yaitu hak akan informasi atau persetujuan tindakan medik. Seorang tenaga kesehatan tidak perlu kecewa atau berkecil hati, ketika pasiennya ingin menguji saran tindakan pengobatan yang akan diterapkan terhadap dirinya kepada tenaga kesehatan atau ahli kesehatan lainnya, karena itu adalah hak pasien. Pendapat lain pasien akan lebih pasti dan mantap terhadap pengobatan yang akan diterimanya.

Setiap orang berhak atas rahasia kondisi kesehatan pribadinya yang telah dikemukakan kepada penyelenggara pelayanan kesehatan. Hak atas rahasia kondisi kesehatan pribadi tidak berlaku dalam hal: ${ }^{13}$

1. Perintah undang-undang.

2. Perintah pengadilan.

3. Izin yang bersangkutan.

4. Kepentingan masyarakat.

5. Kepentingan orang tersebut.

12 Sri Siswati, Etika dan Hukum Kesehatan dalam Perspektif Undang-undang Kesehatan, PT Raja Grafindo Persada, Depok, 2017, hlm. 55.

$13 \mathrm{lbid}, \mathrm{hlm}$. 56. 
Hak lain yang dimiliki pasien atau masyarakat adalah menuntut ganti rugi terhadap seseorang, tenaga kesehatan, dan/atau penyelenggara kesehatan yang menimbulkan kerugian akibat kesalahan atau kelalaian dalam pelayanan kesehatan yang diterimanya. Tuntutan ganti rugi tidak berlaku bagi tenaga kesehatan yang melakukan tindakan penyelamatan nyawa atau pencegahan kecacatan seseorang dalam keadaan darurat, tetapi tuntutan ganti rugi berlaku bagi pembocoran rahasia kedokteran.

Praktik kedokteran bukanlah pekerjaan yang dapat dilakukan oleh siapa saja, melainkan hanya boleh dilakukan oleh kelompok profesional kedokteran tertentu yang berkompetensi dan memenuhi standar tertentu dan telah mendapat izin dari institusi yang berwenang, serta bekerja sesuai dengan standar dan profesionalisme yang ditetapkan oleh organisasi profesi.

Berdasarkan uraian di atas dapat disimpulkan bahwa sebagian tanggung jawab dokter adalah sebagai berikut : ${ }^{14}$

1. Melaksanakan tugas fungsi sesuai dengan keilmuan melalui pendidikan yang berjenjang.

2. Sesuai dengan kompetensi dan memenuhi standar tertentu.

3. Mendapat izin dari institusi yang berwenang.

4. Bekerja sesuai dengan standar profesi.

Hal tersebut di atas juga/tertuang dalam Pasal 1 Ayat (11) Undang-undang Nomor 29 Tahun 2004 tentang Praktek Kedokteran, yang berbunyi : Profesi kedokteran atau kedokteran gigi adalah suatu pekerjaan kedokteran atau kedokteran gigi yang dilaksanakan berdasarkan suatu keilmuan, kompetensi, yang diperoleh melalui pendidikan yang berjenjang, dan kode etik yang bersifat melayani masyarakat.

Dalam menjalankan tugas profesi, dokter senantiasa harus memerhatikan kewajiban sebagai petugas kesehatan. Kewajiban-kewajiban tersebut sesuai dengan yang diamanatkan dalam KODEKI (Kode Etik Kedokteran), yaitu : Pasal 1, yang berbunyi, setiap dokter harus menjunjung tinggi, menghayati, dan mengamalkan sumpah dokter. Pasal 2, yang berbunyi, seorang dokter

14 M. Jusuf Hanafiah, Etika Kedokteran dan Hukum Kesehatan, EGC, Jakarta, 2009, hlm. 56. harus senantiasa melakukan profesinya menurut ukuran yang tertinggi.

Yang dimaksud dengan ukuran tertinggi dalam butir ini ialah bahwa seorang dokter hendaklah memberi pelayanan kedokteran atau kesehatan sesuai kemajuan iptek kedokteran yang mutakhir, dilandasi etik kedokteran, hukum, dan agama. Tentulah dalam pelayanan kedokteran atau kesehatan itu harus tersedia sarana yang memadai dan ditentukan pula mutu pelayanan itu oleh kemampuan pasien atau keluarganya. Namun, yang paling penting diperhatikan adalah standar pelayanan kedokteran yang diberikan dan tanggung jawab dokter bukan saja terhadap sesama manusia, tetapi juga terhadap Tuhan Yang Maha Esa. Pasien atau keluarganya akan menerima apa pun hasil upaya penyembuhan seorang dokter, asalkan dokter tersebut telah dengan sungguh-sungguh berusaha sesuai dengan keahliannya. Pelayanan di bawah standar atau kelalaian seorang dokter dapat memengaruhi pendapat orang banyak terhadap seluruh korps dokter. ${ }^{15}$

Pasal 3, KODEKI, yang berbunyi, dalam melakukan pekerjaan kedokterannya, seorang dokter tidak boleh dipengaruhi oleh pertimbangan keuntungan pribadi.

Semua butir KODEKI mengandung makna betapa luhurnya profesi dokter. Meskipun dalam menjalankan tugasnya dokter berhak memperoleh imbalan, namun dalam hal ini tidak boleh disamakan dengan usaha atau pelayanan jasa yang lain. Profesi kedokteran lebih merupakan panggilan perikemanusiaan dengan mendahulukan keselamatan dan kepentingan pasien, dan tidak mengutamakan kepentingan pribadi. Dalam pelayanan kedokteran tidak dikenal tarif dokter yang tetap (fix), tetapi yang wajar sesuai kemampuan pasien atau keluarganya. Termasuk dalam upaya mencari keuntungan pribadi adalah menjual obat atau sampel di tempat praktik (kecuali tidak ada apotek di kota itu), dan mengarahkan pasien membeli obat tertentu karena dokter telah menerima komisi atau imbalan dari perusahaan farmasi. Juga termasuk mencari keuntungan pribadi adalah melakukan tindakan medis yang tidak diperlukan, menyuruh pasien berobat berulang

15 Ibid, hlm. 57. 
kali atau dokter berkunjung ke rumah pasien berkali-kali tanpa indikasi yang jelas, membuat iklan atau promosi yang berlebihan, merujuk pasien ke laboratorium atau sejawat atau bagian pelayanan dengan imbalan tertentu (komisi), menjual nama (dalam arti tidak pernah langsung melayani pasien, tetapi dilayani orang-orang lain yang tidak kompeten). ${ }^{16}$

Perlindungan hukum terhadap hak pasien dalam pelayanan kesehatan berdasarkan Undang-undang Nomor 36 Tahun 2009 diatur dalam Pasal 58 yang menentukan ;

(1) Setiap orang berhak menuntut ganti rugi terhadap seseorang, tenaga kesehatan, dan/atau penyelenggara kesehatan yang menimbulkan kerugian akibat kesalahan atau kelalaian dalam pelayanan kesehatan yang diterimanya.

(2) Tuntutan ganti rugi sebagaimana dimaksud pada ayat (1) tidak berlaku bagi tenaga kesehatan yang melakukan tindakan penyelamatan nyawa atau pencegahan kecacatan seseorang dalam keadaan darurat.

Berdasarkan pada ketentuan Pasal 58 Undang-undang Nomor 36 Tahun 2009, dapat dipahami bahwa perlindungan hukum terhadap hak pasien dalam pelayanan kesehatan berdasarkan Undang-undang Kesehatan adalah perlindungan hak pasien melalui gugatan perdata untuk menuntut ganti rugi. Dalam kerangka melindungi hak pasien, undang-undang memberikan hak gugat kepada pasien, apabila terjadi pelayanan yang tidak sesuai dengan standar pelayanan, atau sering disebut malpraktik. ${ }^{17}$

Malpraktik dapat terjadi karena tindakan disengaja, seperti pada kelakuan buruk tertentu, tindakan kelalaian ataupun suatu ketidakmahiran atau ketidak-kompetenan yang tidak beralasan. ${ }^{18}$

Rumah sakit merupakan badan hukum dan atau merupakan korporasi yang dapat dimintai pertanggungjawaban apabila terjadi peristiwa yang merugikan pasien. Dalam dunia kedokteran terdapat dua pihak yang bisa

\footnotetext{
16 Loc-cit.

17 Zahir Rusyad, Hukum Perlindungan Pasien, Setara Press, Malang, 2018, hlm. 82.

18 Nusye Ki Jayanti, Penyelesaian Hukum dalam Malpraktik Kedokteran, PT Buku Kita, Jakarta, 2009, hlm. 96.
}

menjadi penanggung jawab yaitu institusi penyelenggara pelayan kedokteran (rumah sakit atau penyedia jasa kesehatan) dan profesional pelaksana pelayanan kedokteran (dokter, dokter gigi, perawat, dsb). ${ }^{19}$

Berkaitan dengan ethical malpractice, berlaku standard profesi kedokteran yang terdapat dalam kode etik kedokteran. Kode etik bukanlah peraturan perundang-undangan karena ia hanya bersifat petunjuk perilaku. Karena bersifat petunjuk, maka tidak semuanya mudah diketahui jika terjadi penyimpangan atau pelanggaran, apalagi untuk membuktikannya. la lebih bersifat himbauan yang sejalan dengan lafal sumpah yang berbunyi, "Saya akan memelihara dengan sekuat tenaga martabat dan tradisi luhur jabatan kedokteran". Jika dokter ingin mematuhi lafal tersebut, petunjuk-petunjuk dalam kode etik dapat dijadikan pedoman. Tetapi tidak berarti semua yang tercantum dalam kode etik tidak dapat diancam hukuman melalui undang-undang. Beberapa larangan dalam kode etik kedokteran dapat diancam dengan hukuman jika dilanggar. Misalnya, memberikan surat keterangan palsu. ${ }^{20}$

Terhadap pelanggaran kode etik yang tidak dapat diancam hukuman melalui undang-undang dapat pula dikenakan hukuman oleh masyarakat profesi kedokteran sendiri. Karena pada umumnya hanya mereka yang dapat mengetahui terjadinya penyimpangan serta kadar penyimpangannya. Untuk dapat menjalankan fungsi ini, selayaknya Majelis Kode Etik Kedokteran Indonesia atau Muktamar menyusun peraturan-peraturan atau mekanisme untuk mendeteksi serta mengadili anggotanya yang melakukan pelanggaran. Termasuk pula macam dan tingkat hukuman yang diancamkan. Karena, hanya dengan peraturan atau mekanisme tertulis semacam itu konsistensi sikap dan objektivitasnya lebih dapat dijamin.

Gugatan perlindungan hukum terhadap hak pasien melalui perdata adalah gugatan yang beralasan sebagai berikut $:^{21}$

19 Syahrul Mahcmud, Penegakan Hukum dan Perlindungan Hukum Bagi Dokter yang Melakukan Medikal Malpraktik, Karya Putra Darwati, Bandung, 2012, hIm. 160.

20 Loc-cit.

21 Ibid, hl,. 161. 
1. Terganggunya kesehatan, cacat atau kematian yang terjadi karena kesalahan atau kelalaian.

2. Diduga memberikan pelayanan yang tidak sesuai dengan standard.

Kedua alasan gugatan sepertinya wajar dan mudah untuk diungkapkan sebagai sebab terjadinya upaya hukum, akan tetapi bagaimana mungkin pihak pasien dapat membuktikan adanya kesalahan dokter dan pelayanan rumah sakit yang tidak sesuai dengan standard, apabila ternyata kedua hal tersebut masih berada di dalam menara gading yang disebut Kode Etik Kedokteran, sehingga hanya dokter dan rumah sakitlah yang tahu mengenai bal tersebut. Pasien dan pihak-pihak penegak hukum pada kenyataannya berada di luar menara gading tersebut.

Hal yang demikian juga tampak pada persidangan di Pengadilan Negeri (PN) Manado, dr. Ayu dkk. dituntut 10 bulan penjara. Tapi dr. Ayu divonis bebas karena tidak terbukti melakukan malpraktik. Jaksa Penuntut Umum (]FU) yang menangani kasus itu mengajukan kasasi dan dikabulkan MA lewat putusan yang dikeluarkan pada 18 November 2012 lalu. Kasasi ini memerintahkan dokter Ayu, cs untuk dipenjara selama 10 bulan. Para dokter di seluruh tanah air turun ke jalan untuk meminta dr. Ayu cs dibebaskan. Bahkan para dokter melakukan aksi mogok hampir di seluruh provinsi karena berduka atas hukuman dr. Ayu cs. Aksi para dokter ini membuahkan hasil. Pada Februari 2014, dr. Ayu cs dibebaskan lewat putusan di tingkat peninjauan kembali (PK). Dasar pertimbangan mengabulkan PK yaitu para terpidana tidak me-nyalahi SOP dalam penanganan operasi sesco ciceasria sehingga pertimbangan judex facti pada PN Manado sudah tepat dan benar. Pertimbangan ini dihasilkan dari penjelasan saksi ahli kedokteran yang biasanya tidak dapat disangkal oleh Hakim.

Esmi Warassih mengungkapkan bahwa suatu konsep juga dituntut untuk mengandung arti (meaningful), karena ia bertujuan untuk memberikan informasi. Sebagai contoh misalnya konsep hak, kewajiban, kesalahan dan seterusnya merupakan sesuatu yang abstrak, sehingga menyebabkan orang sulit memahaminya, dan bahkan dapat memberikan penafsiran yang berbeda pula. ${ }^{22}$

\section{PENUTUP}

\section{A. Kesimpulan}

1. Wewenang dokter dalam pelayanan kesehatan adalah mewawancarai pasien, memeriksa fisik dan mental pasien, menentukan pemeriksaan penunjang, melakukan diagnose, menentukan pengobatan pasien, menulis resep dan alat kesehatan, meracik dan menyerahkan obat kepada pasien yang harus didasarkan pada kaidah moral yakni menghormati martabat manusia, berbuat baik, tidak berbuat yang merugikan pasien dan keadilan.

2. Perlindungan hukum terhadap hak pasien dalam pelayanan kesehatan berdasarkan Undang-undang Nomor 36 Tahun 2009 diberikan dalam bentuk hak gugat perdata untuk menuntut ganti rugi dalam hal pelayanan kesehatan telah menimbulkan kerugian pasien akibat kesalahan atau kelalaian dalam pelayanan kesehatan yang diterimanya berupa terganggunya kesehatan atau cacat karena pelayanan kesehatan yang tidak sesuai standard.

\section{B. Saran}

1. Diharapkan dokter dalam pelayanan kesehatan melakukan wewenangnya dengan penuh tanggung jawab dan senantiasa meningkatkan pengetahuan dan keterampilan berdasarkan perkembangan ilmu pengetahuan dan teknologi agar dapat memberikan pelayanan prima kepada pasien.

2. Diharapkan perlindungan hukum terhadap hak pasien dalam pelayanan kesehatan berupa hak gugat perdata untuk menuntut ganti rugi diatur secara komprehensif dalam Undang-undang Kesehatan yang akan datang atau dalam pembaharuan Undang-undang Kesehatan misalnya tentang besarnya ganti rugi yang menjadi hak pasien terutama ketika pelayanan kesehatan

22 Esmi Warrasih, Pranata Hukum Sebuah Telaah Sosiologis, Pustaka Magister, Semarang, 2013, hlm. 107. 
telah mengakibatkan pasien menderita cacat karena pelayanan kesehatan yang tidak sesuai standard.

\section{DAFTAR PUSTAKA}

Adriyati, dkk., Penyelenggaraan Praktik Kedokteran yang Baik di Indonesia, Konsil Kedokteran Indonesia, Jakarta, 2006.

Aminudin, dan Abidin H. Zainal, Pengantar Metode Penelitian Hukum, PT Raja Grafindo Persada, Jakarta, 2008.

Asyhadie H. Zaeni, Aspek-aspek Hukum Kesehatan di Indonesia, PT Raja Grafindo Persada, Depok, 2018.

Bafen Faig, Hukum Kesehatan, PT Citra Aditya Bakti, Bandung, 2010.

Departemen Pendidikan Dan Kebudayaan, Kamus Besar Bahasa Indonesia, Balai Pustaka, Jakarta, 1989.

Geme Maria Theresia, Perlindungan Hukum Terhadap Masyarakat Hukum Adat Dalam Pengelolaan Cagar Alam Watu Ata Kabupaten Ngada, Provinsi Nusa Tenggara Timur, Disertasi Program Dokt6or IImu Hukum Fakultas Hukum Universitas Brawijaya Malang, 2012.

H.S. H. Salim, dan Nurbani Erlies Septiani, Penerapan Teori Hukum Pada Penelitian Tesis Dan Disertasi, PT Raja Grafindo Persada, Jakarta, 2013.

Hadjon Phillipus M., Perlindungan Hukum Bagi Rakyat Indonesia, PT Bina Ilmu, Surabaya, 1987.

Hanafiah M. Jusuf, Etika Kedokteran dan Hukum Kesehatan, EGC, Jakarta, 2009.

Jayanti Nusye Ki, Penyelesaian Hukum dalam Malpraktik Kedokteran, PT Buku Kita, Jakarta, 2009.

Kansil C.S.T., Pengantar IImu Hukum dan teta Hukum Indonesia, Balai Pustaka, Jakarta.

Mahcmud Syahrul, Penegakan Hukum dan Perlindungan Hukum Bagi Dokter yang Melakukan Medikal Malpraktik, Karya Putra Darwati, Bandung, 2012.

Mertokusumo Sudikno, Mengenal Hukum Suatu Pengantar, Liberty, Yogyakarta, 1999.

Nasution Bahder Johan, Hukum Kesehatan Pertanggung jawaban Dokter, Rineka Cipta, Jakarta, 2015.

Raharjo Satjipto, Ilmu Hukum, PT Citra Aditya Bakti, Bandung, 2000.
Raharjo Satjipto, Penyelenggaraan Keadilan dalam Masyarakat yang Sedang Berubah, Ghalia Indonesia, 2012.

Rahayu Srikandi, Seputar Pengertian Perlindungan Hukum, PT Citra Aditya Bakti, Bandung, 2000.

Rasyid Zahir, Hukum Perlindungan Pasien, Setara Press, Malang, 2018.

Rasyidi Lili, Filsafat Hukum, Remadja Karya, Bandung, 1988.

Rusyad Zahir, Hukum Perlindungan Pasien, Setara Press, Malang, 2018.

S.J. A. Heuken, dkk., Ensiklopedi Politik Pembangunan Pancasila, Yayasan Cipta Loka Caraka, Jakarta, 2003.

Siswanto Arie, Hukum Persaingan Usaha, Ghalia Indonesia, Jakarta, 2004.

Siswati Sri, Etika dan Hukum Kesehatan dalam Perspektif Undang-undang Kesehatan, PT Raja Grafindo Persada, Depok, 2017.

Warrasih Esmi, Pranata Hukum Sebuah Telaah Sosiologis, Pustaka Magister, Semarang, 2013. 